\title{
A clinical dilemma: Malignant adenomyoepithelioma of the breast - case report and review of literature
}

\author{
Ahmad SS*1, Hassan $\mathrm{M}^{2}$, Alam $\mathrm{S}^{2}$, Aftab $\mathrm{F}^{2}$ \\ ${ }^{1}$ Letterkenny University Hospital, Republic of Ireland \\ ${ }^{2}$ Mallow General Hospital, Republic of Ireland
}

Received: July 20, 2015

DOI: $10.5430 /$ css.v2n1p64
Accepted: October 21, $2015 \quad$ Online Published: November 20, 2015

URL: http://dx.doi.org/10.5430/css.v2n1p64

\begin{abstract}
Malignant myoepithelioma of the breast is a rare lesion characterized by the malignant proliferation of the epithelial and myoepithelial cells that exhibit characteristic histological and immuno- histochemical features. Very few cases have been reported in literature. We report a case of a 64-year-old female with a palpable lump in the upper outer quadrant of her right breast, present for a number of years. She underwent lumpectomy under local anesthesia. Upon histological confirmation of the diagnosis of malignant myoepithelioma, the patient underwent wide local excision with sentinel node mapping. Malignancy was evident by extensive central infarction. The tumour was completely triple negative, i.e. Estrogen receptor (ER), Progesterone receptor (PR) and Human epidermal growth factor receptor 2 (HER2) negative. The patient also underwent adjuvant chemotherapy and radiation therapy. The patient remains well with no recurrence 7 years since her initial surgery. The authors believe, that due to the paucity of these rare tumours, optimal treatment strategies remain to be determined.
\end{abstract}

Key Words: Breast, Adenomyoepithelioma, Mammography, Mastectomy, Wide local excision, Chemotherapy, Radiotherapy

\section{INTRODUCTION}

Malignant adenomyoepithelioma (AME) of the breast is a rare lesion with around 30 cases reported in the literature, therefore the true incidence is difficult to compute. It is characterized by malignant proliferation of epithelial and myoepithelial cells with characteristic histological and immunohistochemical features. Irregular invasive margins (with surrounding stromal reaction), cellular atypia and pleomorphism, necrosis, and a high mitotic count throughout the tumor are indicative of malignant growth. In addition, overgrowth of myoepithelial cells, high cellularity and satellite foci are also considered features of malignancy. Histologically, myoepithelial cells may be difficult to recognize. Lack of familiarity with their range of appearances may, at least in part, be responsible for the paucity of recognized cases. First described by Hamperl in 1970, ${ }^{[1]}$ most tumours are benign, but malignant degeneration, although unusual, may occur. AME have been classified as tubular, lobulated, or spindle variants, on the basis of their growth pattern. ${ }^{[2]}$ Malignant neoplasms have been described in many patterns and have been sub-classified as: undifferentiated, ${ }^{[3]}$ myoepithelial, or epithelial. It has been reported in women ranging in age from 26 to 80 years. Metastasis, only documented in tumours $2.0 \mathrm{~cm}$ or larger, appear to be hematogenous rather than lymphatic. ${ }^{[4-8]}$ The best predictor for local recurrence is the surgical margin. Negative margins reduces local recurrence rates, there is no consensus on what constitutes an adequate negative margin. If the excision margin is nar-

*Correspondence: Ahmad SS; Email: ahmad_sohail5@yahoo.com; Address: Letterkenny University Hospital, Republic of Ireland. 
row or incomplete, re-excision to gain adequate margins is recommended.

\section{CASE REPORT}

The patient, a 64-year-old female, presented to the surgical clinic with a palpable lump in the upper outer quadrant of her right breast, present for a number of years, with recent enlargement and no palpable axillary lymphadenopathy. She previously underwent an excision of a benign cyst from the same breast 5 years ago. The patient was postmenopausal for 15 years, on hormone replacement therapy for 8 years, with no family history of breast cancer, and had never been on the oral contraceptive pill. She had 6 children. She underwent lumpectomy under local anesthesia. Histologically, it was reported as malignant AME of the breast. Due to rarity of the condition and paucity of information in literature and after discussion at the multidisciplinary tumour board meeting, the patient underwent wide local excision with sentinel node mapping. The excised specimen was a well circumscribed, white, firm and gritty nodule measuring $0.7 \mathrm{~cm} \times 0.5 \mathrm{~cm} \times$ $1 \mathrm{~cm}$ in dimension. This lesion was delineated by fibrous tissue with prominent chronic inflammation incorporating abundant plasma cells, central fibrinoid necrosis with peripheral ductular structures and increased number of myoeipthelial cells (see Figure 1). The epithelial elements were admixed with sclerotic type amterial, focal mitosis and cellular atypia (see Figure 2). Immunostaining for p63 and CK5-6 confirmed the presence of AME. Malignancy in the current case was evident by extensive central infarction while the periphery of the lesion consisted of ductular type structures. The tumour was completely triple negative, that is, Estrogen receptor (ER) negative, Progesterone receptor (PR) negative and Human epidermal growth factor receptor 2 (HER2) negative. She received 6 cycles of adjuvant chemotherapy consisting of adriamycin, cyclophosphamide, and 5 flurouracil and radiation therapy, consisting of $60 \mathrm{~Gy}$ to the tumour bed with $50 \mathrm{~Gy}$ to the rest of her right breast. She is now 7 years since her initial diagnosis, and has done well with no recurrence.

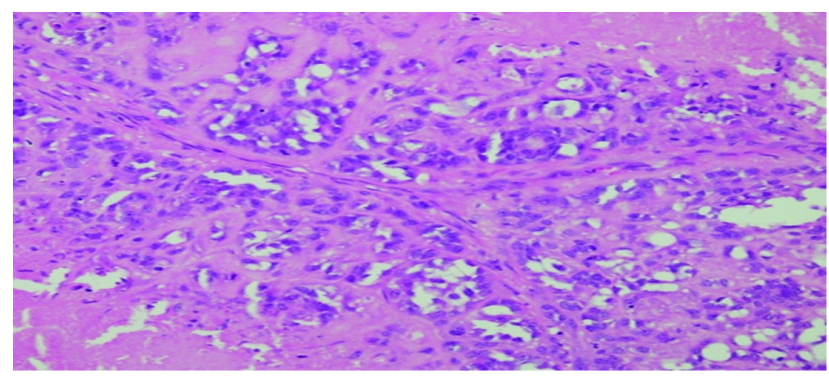

Figure 1. Histopathological imaging of malignant AME showing epithelial forming glandular structures and myoepithelial spindle cell areas

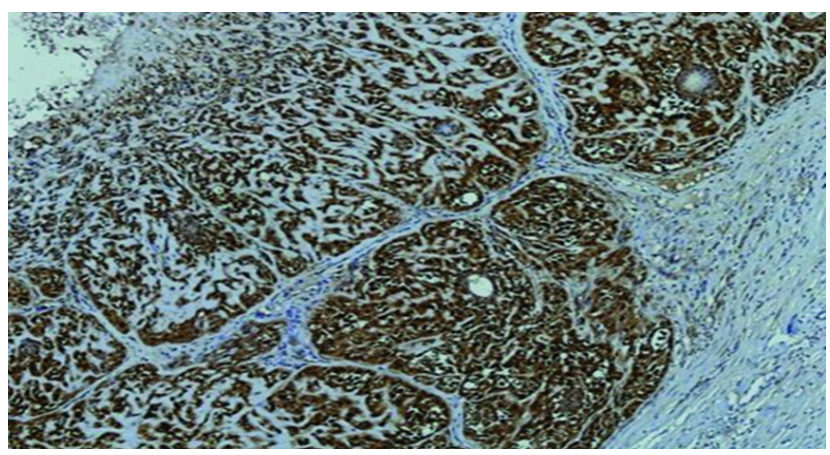

Figure 2. Histopathological imaging of the malignant AME showing spindle cell areas with increased mitotic activity

\section{Discussion}

Myoepithelioma of the breast is a rare tumour. It usually presents as a palpable nodule. The duration of symptoms may range from several weeks to several months. ${ }^{[2]}$ Clinically tenderness and serous nipple discharge have been found infrequently. ${ }^{[2]}$ On mammography, AME appears as a round or lobulated, dense, mostly circumscribed mass, sometimes with partially indistinct margins. ${ }^{[7]}$ The diagnosis of AME on a needle core biopsy can be challenging because of the morphologic heterogeneity. In limited biopsy material, the sampled tissue may even be mistaken for invasive carcinoma, especially in tumors that have compact glandular structures with clear cell epithelioid myoepithelial proliferation. ${ }^{[9,10]}$ Excisional biopsy is therefore, recommended to rule out a carcinoma arising in an AME. ${ }^{[1]}$ World health organization (WHO) classification of tumours (Tumours of the breast and female genital organs), ${ }^{[5]}$ defines malignant myoepithelioma as an infiltrating tumour composed purely of myoepithelial cells (predominantly spindled), with identifiable mitotic activity (see Table 1). Tavassoli ${ }^{[5]}$ proposed a classification system of myoepithelial lesions of the breast, sub-classifying into: myoepitheliosis, AME and malignant myoepithelioma. The same author classified AME as spindle cell, lobulated, and tubular (or adenosis) types with carcinoma arising in AME. Myoepitheliomas may vary in size from $1 \mathrm{~cm}$ to $21 \mathrm{~cm}$. Malignant AME has been reported in women only, with an 80-year-old female as the oldest patient. ${ }^{[12]}$ Kurashini et al. ${ }^{[13]}$ reported malignant myoepithelioma consisting mainly of spindle-shaped cells admixed with a few epithelial cells. They reported nuclear atypia with hyperchromasia and prominent nucleoli, occasional intranuclear cytoplasmic inclusions and mitoses. The evolution of malignant AME seems to begin with adenosis, with or without myoepithelial hyperplasia, proceeding to benign AME, and ending in a malignant tumor that still may contain residues of its precursor lesion. ${ }^{[6]}$ Because of the varied and hypercellular nature of these tumors, diagnosis by cytology is difficult ${ }^{[14]}$ and core biopsy may be more accurate. The $X$-ray appearance of 
myoepithelial carcinoma appears to be non-specific. ${ }^{[15]}$

Table 1. WHO Classification of myoepithelial lesion of the breast

\begin{tabular}{|l|}
\hline 1. Myoepitheliosis \\
a. Intraductal \\
b. Periductal \\
2. Adenomyoepithelial adenosis \\
3. Adenomyoepithelioma \\
a. Benign \\
b. With malignant changes (specify the subtype) \\
• Myoepithelial carcinoma arising in an adenomyoepithelioma \\
• Epithelial carcinoma arising in an adenomyoepithelioma \\
- Malignant epithelial and myoepithelial components \\
- Sarcoma arising in adenomyoepithelioma \\
• Carcinosarcoma arising in adenomyoepithelioma \\
4. Malignant myoepithelioma (myoepithelial carcinoma)
\end{tabular}

Based on the differentiation of the malignancy, the tumors can be divided into monophasic and biphasic. The monophasic malignancy could be invasive ductal carcinoma not otherwise specified, metaplastic carcinoma, low-grade adenosquamous carcinoma ${ }^{[7]}$ invasive lobular carcinoma, ${ }^{[16]}$ and ductal carcinoma in situ, ${ }^{[17,18]}$ arising from epithelial component, or malignant myoepithelioma ${ }^{[19]}$ arising from myoepithelial component. Only 16 biphasic malignant AMEs in which malignancy arising from both epithelial and myoepithelial cells have been reported previously. ${ }^{[6,7,11,20,21]}$ Loose et $a l .{ }^{[4]}$ have proposed a high mitotic rate, cytologic atypia, and infiltrative peripheral border as predictors of malignancy.

The interplay between epithelial and myoepithelial cell elements is highlighted by immunohistochemical staining with antibodies specific for these 2 components. The cytoplasm of epithelial cells uniformly reacts with antibodies to cytokeratins, such as cytokeratin AE1/3, CAM 5.2, or CK7. ${ }^{[4,22]}$ The myoepithelial component is highlighted by p63, smooth muscle myosin heavy chains, CK5, CD10, calponin, actin, and S100. ${ }^{[4,22]}$ McLaren et al. ${ }^{[22]}$ reported that p63 produced the best results. Although histologically similar, the expression of epithelial markers in the mesenchymal components of metaplastic breast carcinoma differentiates it from malignant AME of the breast.

Nipple adenoma may mimic AME, clear cell carcinoma may also mimic AMEs, but that may be differentiated by the presence of both epithelial and myoepithelial cell types, and confirmed with immunohistochemical stains, if necessary. ${ }^{[22]}$ Metaplastic tumors associated with papilloma are also included in the differential diagnoses. ${ }^{[23]}$ When the tumor predominantly displays a spindle cell component, it may morphologically be mistaken for a myoid hamartoma or leiomyoma. ${ }^{[2]}$
Several authors (see Table 2) have reported their experiences of managing this rare and complex disease. The management of the disease in the breast dealt by mastectomy in the vast majority of cases have been described. ${ }^{6,8,13,16,17,20,24]}$ Only 2 patients described by Qureshi et al. ${ }^{[20]}$ and Awaleh et al. ${ }^{[8]}$ underwent excision biopsy and wide local excision, respectively, but later had a completion mastectomy for local recurrences. Petroza et al. ${ }^{[21]}$ described quadrantectomy and axillary sampling for malignant AME for their patient. Jeong S. Han et al. ${ }^{[5]}$ described a 55-year-old patient with a lump in right breast. Subsequent investigations including ultrasound, mammogram and magnetic resonance imaging (MRI) and wire guided localization revealed 3 separate AMEs along with ductal carcinoma in situ (DCIS). The patient underwent multiple lumpectomies and eventually had to undergo total mastectomy.

The optimal management of axilla is also not clear and this has ranged from axillary node sampling to dissection/clearance as reported by various authors. ${ }^{[6,8,15,16,20,21,24]}$ As the disease has hematogenous spread, this in the author's opinion increases the morbidity of the procedure, and perhaps a lesser option would be sentinel lymph node mapping and depending on this further axillary surgery may be considered.

Currently surgical management of this rare malignant tumor is unclear. The treatment is similar to that for other breast malignancies, from lumpectomy to wide local excision/quadrantectomy or mastectomy. The role of surgery to the axilla is less well defined, with observation to axillary sampling and axillary clearance been proposed. ${ }^{[6-8,15]}$ Axillary lymph node involvement is thought to be unusual; hence a recent review article has suggested that axillary node dissection is not indicated unless there are clinically involved lymph nodes. ${ }^{[8]}$ The response to chemotherapy and radiotherapy is unknown. Local recurrence is very common if the excision margin is narrow or incomplete and in such cases, re-excision is recommended. ${ }^{[24]}$ According to Tavossoli ${ }^{[2]}$ et al., most tumors with recurrences were tubular type in type, and extended into, and blending with, the adjacent normal ducts. The recurrent lesions lacked an aggressive morphologic appearance or noticeable mitotic activity. ${ }^{[2]}$ The recurrent tumor with a lobulated variant displayed only cytologic atypia and had an increased mitotic activity with $8 / 10$ high-power fields as compared with 3/10 high-power fields in the original tumor. ${ }^{[2]}$

Malignant AME has the potential for distant metastases. These typically occur in lesions larger than $2 \mathrm{~cm}^{[6]}$ and in those with high-grade malignant component. ${ }^{[7]}$ Distal metastasis involving lungs, brain, liver, bone, thyroid gland, medi- 
astinal lymph nodes and soft tissues have been described. ${ }^{[6-8]}$ Trojani et al. ${ }^{[11]}$ reported a case of malignant AME with lung metastasis. One of the 2 cases reported by Loose et al. ${ }^{[4]}$ also showed lung and brain metastases.

Prognosis of patients with benign AME of the breast is usually good, but it has a potential for local recurrence, espe- cially in the tubular and lobulated variants. Total surgical excision with an adequate margin of uninvolved breast tissue is therefore recommended. ${ }^{[25]}$ Prognosis of malignant AME of the breast with distant metastases is very poor with the time of recurrence varying after initial treatments. Malignant AME should be followed up with careful screening for distant metastases.

Table 2. Few reported cases of malignant AME

\begin{tabular}{|c|c|c|c|c|c|c|c|}
\hline Author & $\begin{array}{l}\text { Age } \\
\text { (yrs) }\end{array}$ & Location of tumor & Investigations & Procedures & $\begin{array}{l}\text { Radiation/ } \\
\text { Chemo-therapy }\end{array}$ & Histology & Met \\
\hline Our patient & 64 & Right Breast & Mammography/US & $\begin{array}{l}\text { Lumpectomy/Wide local } \\
\text { excision and sentinel lymph } \\
\text { node mapping }\end{array}$ & $\begin{array}{l}\text { Chemotherapy and } \\
\text { radiation therapy }\end{array}$ & Malignant adenomyo-epithelioma & No \\
\hline $\begin{array}{l}\text { Suresh Attili VS } \\
\text { et al. }{ }^{[24]}\end{array}$ & 20 & Right Breast & Mammography & $\begin{array}{l}\text { Lumpectomy/Modified } \\
\text { radical mastectomy }\end{array}$ & $\begin{array}{l}\text { Chemotherapy and } \\
\text { radiation to the chest }\end{array}$ & Malignant adenomyo-epithelioma & Yes \\
\hline $\begin{array}{l}\text { D.C. Howlett } \\
\text { et al. }{ }^{[15]}\end{array}$ & 74 & Right Breast & $\begin{array}{l}\text { FNAC/ US/ } \\
\text { Mammography }\end{array}$ & $\begin{array}{l}\text { Right mastectomy and } \\
\text { axillary dissection }\end{array}$ & Not Known & Malignant adenomyo-epithelioma & No \\
\hline Ahmed and Heller ${ }^{[6]}$ & 71 & Right axillary tail & Mammography & $\begin{array}{l}\text { Lumpectomy/Axillary lymph } \\
\text { node dissection }\end{array}$ & No & Malignant adenomyo-epithelioma & No \\
\hline Qureshi et al. ${ }^{[20]}$ & 65 & $\begin{array}{l}\text { Recurrent left breast } \\
\text { mass }\end{array}$ & Mammogram & $\begin{array}{l}\text { Excision } \mathrm{Bx} / 6 \text { months later } \\
\text { mastectomy and axillary } \\
\text { clearance }\end{array}$ & No & $\begin{array}{l}\text { Malignant adenomyoepithelioma of } \\
\text { the breast }\end{array}$ & No \\
\hline $\begin{array}{l}\text { Ahlam. A. Awamleh } \\
\text { et al. }{ }^{[8]}\end{array}$ & 63 & Mass in the left breast & Core Biopsy & $\begin{array}{l}\text { Wide local excision and later } \\
\text { mastectomy and axillary } \\
\text { lymph node sampling }\end{array}$ & Not known & $\begin{array}{l}\text { Malignant adenomyoepithelioma of } \\
\text { the breast }\end{array}$ & Yes \\
\hline $\begin{array}{l}\text { YumiHonda and } \\
\text { Ken-ichi Iyama }^{[16]}\end{array}$ & 53 & $\begin{array}{l}\text { Right breast mass and } \\
\text { nipple discharge }\end{array}$ & Physical examination & $\begin{array}{l}\text { Mastectomy with axillary } \\
\text { lymph node dissection }\end{array}$ & Chemotherapy & $\begin{array}{l}\text { Malignant AME combined with } \\
\text { Invasive lobular } \\
\text { carcinoma/axillary nodes involved }\end{array}$ & Yes \\
\hline Kurashina $\mathbf{M}^{[13]}$ & $\begin{array}{l}\text { (1) } 73 \\
\text { (2) } 73\end{array}$ & $\begin{array}{l}\text { (1) Right breast } \\
\text { tumor, previously left } \\
\text { breast mastectomy } \\
\text { (2) Right breast } \\
\text { tumor }\end{array}$ & (1) CT/US/MRI/FNA & $\begin{array}{l}\text { (1) Local } \\
\text { excision/lumpectomy } \\
\text { (2) Mastectomy }\end{array}$ & No & $\begin{array}{l}\text { (1) Spindle cell variant of malignant } \\
\text { AME } \\
\text { (2) Tubular variant of AME }\end{array}$ & No \\
\hline $\begin{array}{l}\text { Yan Peng, } \\
\text { Jeong S. Han }{ }^{[17]}\end{array}$ & 55 & $\begin{array}{l}\text { Lump in the left } \\
\text { breast }\end{array}$ & $\begin{array}{l}\text { US/Mammogram/MRI } \\
\text { Multi centric lesions } \times 3\end{array}$ & $\begin{array}{l}\text { A needle-localized resection } \\
\text { of the mass lesions was } \\
\text { performed./lumpectomy/mast } \\
\text { ectomy }\end{array}$ & No & $\begin{array}{l}\text { Multicentric adenomyoepithelioma } \\
\text { of the breast with atypia and } \\
\text { associated ductal carcinoma in situ }\end{array}$ & No \\
\hline Petrozza et al. ${ }^{[21]}$ & 60 & $\begin{array}{l}\text { Right breast } \\
\text { mastalgia }\end{array}$ & US/Mammography & $\begin{array}{l}\text { Quadrantectomy with } \\
\text { axillary sampling }\end{array}$ & Radiotherapy & Malignant adenomyoepithelioma & No \\
\hline
\end{tabular}

Note. FNAC: Fine needle aspiration and cytology; US: ultrasound; AME: adenomyoepithelioma, mammography, mastectomy; CT: Computed tomography; MRI: magnetic resonance imaging

\section{Conclusions}

In conclusion, malignant AME is a rare neoplasm. Tumor size can vary. Metastasis may occur, and appears to be hematogenous rather than lymphatic and restricted to tumors $2 \mathrm{~cm}$ or larger. Diagnosis by cytology is difficult, due to the varied and hypercellular nature of these tumors. Core biopsy provides more accurate information. For benign lesions, total excision of the lesion with a margin of uninvolved breast tissue is recommended. However, the management of malignant lesions is unclear, due to the paucity of reported cases. It is treated as any other breast cancer. The role of breast conserving surgery vs. mastectomy is not established and furthermore as mentioned previously, role of adjuvant chemotherapy and radiotherapy is not clear, as there are no clear guidelines in the literature to support it. The authors propose that role of breast conserving surgery should Published by Sciedu Press be paramount and sentinel lymph node mapping should be undertaken in the absence of gross axillary disease.

\section{Consent}

Written informed consent was obtained from the patient and her family for publication of this case report and any accompanying images. A copy of the written consent is available for review by the Editor-in-Chief of this journal.

\section{Author contribution}

The idea was conceived by FA, data and manuscript was written by SSA, review of the literature and research was done by SSA and FA. The article was edited by HM and AS. The final approval of the manuscript was given by FA.

\section{Conflicts of InTEREST Disclosure}

The authors declare that they have no competing interests. 


\section{REFERENCES}

[1] Hamperl H. The myothelia (myoepithelial cells): normal state; regressive changes; hyperplasia; tumors. Curr Top Pathol. 1970; 53 161-220. PMid: 4323195. http://dx.doi.org/10.1007/978-3 -662-30514-0_3

[2] Tavassoli FA. Myoepithelial lesions of the breast: myoepitheliosis, adenomyoepithelioma, and myoepithelial carcinoma. Am J Surg Pathol. 1991; 15: 554-56. PMid: 1709559. http://dx.doi.org/1 0.1097/00000478-199106000-00004

[3] Michal M, Baumruk L, Burger J, et al. Adenomyoepithelioma of the breast with undifferentiated carcinoma component. Histopathology. 1994; 24: 274-276. PMid: 7515373. http://dx.doi.org/10.11 11/j.1365-2559.1994.tb00522.x

[4] Loose JH, Patchefsky AS, Hollander IJ, et al. Adenomyoepithelioma of the breast: a spectrum of biologic behavior. Am J Surg Pathol. 1992; 16: 868-876. PMid: 1384377. http://dx.doi.org/10.10 97/00000478-199209000-00005

[5] Tavassoli FA, Soares J. Myoepithelial lesions in the breast. WHO Classification Tumour Pathology \& Genetics. Tumours of the Breast and female Genital Organs. 2004; 86-88.

[6] Ahmed AA, Heller DS. Malignant adenomyoepithelioma of the breast with malignant proliferation of epithelial and myoepithelial elements: A case report and review of the literature. Arch Pathol Lab Med. 2000; 124: 632-6. PMid: 10747327.

[7] Hayes MM. Adenomyoepithelioma of the breast: a review stressing its propensity for malignant tansformation. Journal of Clinical Pathology. 2011; 64(6): 477-484. PMid: 21307156. http: //dx.doi.org/10.1136/jcp.2010.087718

[8] Awamleh AA, Gudi M, Shousha S. Malignant Adenomyoepithelioma of the Breast with Lymph Node Metastasis: A Detailed Immunohistochemical Study. Case Reports in Pathology. 2012; 2012: 305858-305858

[9] Rosen PP. Adenomyoepithelioma of the breast. Hum Pathol. 1987; 18(12): 1232-1237. http://dx.doi.org/10.1016/S0046-817 7 (87) 80406-9

[10] Zhang C, Quddus MR, Sung CJ. Atypical adenomyoepithelioma of the breast: diagnostic problems and practical approaches in core needle biopsy. Breast J. 2004; 10(2): 154-155. PMid: 15009045. http://dx.doi.org/10.1111/j.1075-122X.2004.21414.x

[11] Trojani M, Guiu M, Trouette H, et al. Malignant adenomyoepithelioma of the breast: an immunohistochemical, cytophotometric and ultrastructural study of a case with lung metastasis. Am J Clin Pathol. 1992; 98: 598-602. PMid: 1334365.

[12] Zizi-Sermpetzoglou A, Vasilakaki T, Grammatoglou X, et al. Malignant adenomyoepithelioma of the breast-case report. Eur J Gynaecol Oncol. 2009; 30(2): 234-6. PMid: 19480267.

[13] Kurashina M. Fine-needle aspiration cytology of benign and malignant adenomyoepithelioma: report of two cases. Diagn Cytopathol. 2002; 26: 29-34. PMid: 11782084. http://dx.doi.org/10.10 $02 / d c .10037$
[14] Lee WY. Fine needle aspiration cytology of adenomyoepithelioma of the breast: A case indistinguishable from phyllodes tumor in cytological findings and clinical behavior. Acta Cytol. 2000; 44: 488-90. PMid: 10834021

[15] Howlett DC, Mason CH, Biswas S, et al. Adenomyoepithelioma of the breast: spectrum of disease with associated imaging and pathology. AJR Am J Roentgenol. 2003; 180: 799-803. PMid: 12591699. http://dx.doi.org/10.2214/ajr.180.3.1800799

[16] Honda Y, Iyama K. Malignant adenomyoepithelioma of the breast combined with invasive lobular carcinoma. Pathol Int. 2009; 59: 179184. PMid: 19261096. http://dx.doi.org/10.1111/j.1440-1 $827.2009 .02347 . \mathrm{x}$

[17] Han JS, Peng Y. Multicentric adenomyoepithelioma of the breast with atypia and associated ductal carcinoma in situ. Breast J. 2010; 16: 547-549. PMid: 20604795. http://dx.doi.org/10.1111/j $.1524-4741.2010 .00954 . x$

[18] Warrier S, Hwang S, Ghaly M, et al. Adenomyoepithelioma with ductal carcinoma in situ: a case report and review of the literature. Case Rep Surg. 2013; 2013: 521417. http://dx.doi .org/10.11 $55 / 2013 / 521417$

[19] Marian C, Boila A, Soanca D, et al. Malignant transformation of adenomyoepithelioma of the breast by a monophasic population: a report of two cases and review of literature. APMIS. 2013; 121: 272-279. PMid: 23030630. http://dx.doi.org/10.1111/j.1600-0463. 2012.02982.x

[20] Qureshi A, Kayani N, Gulzar R. Malignant adenomyoepithelioma of the breast: a case report with review of literature. BMJ Case Rep. 2009; 2009: pii: bcr01.2009.1442.

[21] Petrozza V, Pasciuti G, Pacchiarotti A, et al. Breast adenomyoepithelioma: a case report with malignant proliferation of epithelial and myoepithelial elements. World J Surg Oncol. 2013; 11: 285. PMid: 24171817. http://dx.doi.org/10.1186/1477-7819-11-285

[22] McLaren BK, Smith J, Schuyler PA, et al. Adenomyoepithelioma: clinical, histologic, and immunohistologic evaluation of a series of related lesions. Am J Surg Pathol. 2005; 29(10): 1294-1299. PMid: 16160470. http://dx.doi.org/10.1097/01.pas.0000 164615.38200 .86

[23] Gobbi H, Simpson JF, Jensen RA, et al. Metaplastic spindle cell breast tumors arising within papillomas, complex sclerosing lesions, and nipple adenomas. Mod Pathol. 2003; 16(9): 893-901. PMid: 13679453. http://dx.doi.org/10.1097/01.MP.0000085027. $75201 . \mathrm{B} 5$

[24] Riman BH, Akpan SE. Healthcare Financing and Health outcomes in Nigeria: A State Level Study using Multivariate Analysis. International Journal of Humanities and Social Science. 2012; 2(15): 209-312.

[25] Satyanarayana V, Gole S. Adenomyoepithelioma A Rare Breast Tumor: Case Studies With Review Of The Literature. The Internet Journal of Pathology. 2012. 